\title{
REGIONAL BRANDING: CUSTOMER'S EXPERIENCE WITH THE CERTIFIED PRODUCTS
}

\author{
Klára Margarisová1, Lucie Vokáčová1, Kateřina Kuralovái ${ }^{1}$ Tomáš Hlavsa ${ }^{1}$ \\ ${ }^{1}$ Department of Management, Faculty of Economics and Management, Czech University of Life Sciences Prague, \\ Kamýcká 129, 16521 Prague, Czech Republic
}

To cite this article: MARGARISOVÁ KLÁRA, VOKÁČOVÁ LUCIE, KURALOVÁ KATEŘINA, HLAVSA TOMÁŠ. 2018. Regional Branding: Customer's Experience with the Certified Products. Acta Universitatis Agriculturae et Silviculturae Mendelianae Brunensis, 66(6): 1549-1556.

To link to this article: https://doi.org/10.11118/actaun201866061549

\begin{abstract}
This article focuses on the experience of Czech customers with the purchase of products labelled by the Association of Regional Brands and Bohemian Paradise Association ${ }^{1 .}$ The aim of this paper is to evaluate selected indicators associated with purchasing certified regional products. The studied characteristics focus on the knowledge and perception of several chosen microregional brands and on the purchase of a certified product itself. The article presents the results of research conducted through a questionnaire survey, whose 1390 respondents are residents as well as visitors of eight different micro-regions in the Czech Republic. Awareness of regional brands within the sample surveyed is around $46 \%$. The relationship between awareness of regional brand and respondents' age, education and status towards the region has been identified. The perception of consumers considered, a brand is most often associated with tangible products, namely food and agricultural produce. Consumers view brands chiefly as a guarantee of production in the given region and a certain tradition. Most often, the respondents take notice of brands on the packaging of a particular certified product.
\end{abstract}

Keywords: region, regional product, sustainable development, regional branding, purchasing behaviour, customer's experience, association of regional brands

\section{INTRODUCTION}

The labelling of regional products by awarding a certificate on the basis of an assessment of the relevant criteria by an independent entity, thereby guaranteeing compliance with them, is preceded by the spontaneous naming of products according to place of origin or region. A region can generally be defined as a part of a geographical area characterized by a complex of natural and socio-economic elements and relationships and processes, and which differs from other parts due to its unanimity, uniformity or consistency of features, or a certain organizational principle (Chromý, 2009). In this sense, a region can then be defined as a specific territory with certain elements, in which there is a specific, functional and related infrastructure, and a common interest (of the population, social groups, institutions and companies) in its development (economic development, employment, quality of life, etc.) and increasing the well-being of the population are promoted. A region thus represents a system with a target behaviour. The expression and instrument of support for this cooperation can be clusters - groups of companies and other

1 Bohemian Paradise Regional Product 
institutions for mediation of contacts, information and resources (Skokan, 2004; Blažek et al., 2013; Lee et al., 2016; Mauroner and Zorn, 2017).

The production of quality and regionally-specific products can contribute significantly to the economy and social stability of a rural area by improving the incomes of producers, and by creating higher qualification job opportunities. The quality improvement path (entry into quality and origin guarantee programs) is an alternative to routine production, in particular in areas and for products where the economy is limited by resources (e.g. land, water) or regulations. However, entry into quality programs is linked to transaction and transit costs that can discourage producers from conversion. Significant transaction costs include obtaining information, transferring knowledge (developing a quality product) and improving the quality of work (qualifications and discipline).

The term "local", which occurs in the context of the term "regional product", raises a discussion of what "local" really means in this case. Some authors (Sims, 2009; Watts et al., 2005 in Hrubalová, and Budzel'ová, 2017) distinguish a strict definition emphasizing the use of local raw materials in production, and benevolent definitions allow for the processing of imported raw materials by local producers. According to Morris and Buller (2003 in Hrubalová and Budzel'ová, 2017), the term "local" refers to a geographically-limited region where the products are manufactured and sold, or to "specialties" with a certain added value allowing for export outside the region. In this case, the "local" brand is more important, and the product does not necessarily have to be manufactured, purchased and consumed in the given region. For the efficient use of regional products and demand support, it is necessary to define a regional product from a customer perspective (Rudawska, 2014). Whilst manufacturers place greater emphasis on the origin of raw materials and the production process, the consumer rather perceives the symbolic aspect of local products (e.g. product name emphasizing relevance to the given region).

Kirchgeorg (2005 in Kaufmann and Durst, 2008) distinguishes regions brands from regional brands as the latter one are limited to a specific geographic area and the promotion of the regions' specific products or services, whereas regions brands promotes the overall product or service bundle of a region. Another similar link is place branding (Kašková et al., 2016; Šifta and Chromý, 2017).

Other synonyms are available for calling something "regional", e.g. territorial, provincial, domestic, etc. With regard to regional foods, expressions appear such as "old Czech", "grandmother's", "traditional", "original", "rural", "farmer", etc., which are meant to give customers the impression of an honest/quality product. There is no limit to adding such attributes to the names of foodstuffs; with a few exceptions, at present only the words "live", "fresh", "natural", "domestic" and "rational" cannot be used on packaging. The phrase "Czech food", with which can only be labelled products wholly or partly made from Czech raw materials, has gained a very specific meaning. Single-component products, such as peas, honey or wine must be completely Czech. Foods containing multiple raw materials must have at least $75 \%$ domestic ingredients. A new Decree, No. 417/2016 Coll., also implements a special logo that Czech foods (dTest, 2017) can be labelled with.

Regional branding is one of the ways how to promote rural regions and support development of socially and environmentally oriented economies in areas that are interesting due to their natural and cultural heritage (Čadilová, 2011; Kažmierski, 2013; Kažmierski, 2014). The regional designation concept respect to all three pillars of sustainable development - the 3Ps as 'People, Planet, Profit' (Elkington, 1997). The group that is provided most of the support includes local business people, i.e. handicraftsmen, farmers, small and medium-sized enterprises, who products help to spread the region's renown, and, at the same time, identifi cation with the region represents a great marketing opportunity for them.

A regional label is a marketing tool for the visualization of quality products, services and experiences with guaranteed origin from a particular region (Hruška et al., 2017). Regional brands contribute to development of sustainable tourism as they enable tourists to find their bearing when shopping in different regions (Minta, 2015).

The labels associated in the Association of Regional Marks (ARZ) have the following: a common visual (together with their own symbols and names), common rules for awarding, a coordinator and certification committee in the region, coordination at the national level covering methodology and promotion, and a portal on regional labelling on which is focused information on all brands and all holders of their certificates. ARZ currently has 27 member regions, and there are over 1,017 valid certificates for products, 88 for services and 65 for experiences; however, these numbers change with each additional certification committee. A label's goal is to primarily support very small businesses, craftsmen and environmentally sustainable businesses. The conditions for awarding include: production in the region, guaranteeing the standard quality and respect for nature and 'uniqueness' in relation to the locality, which is judged by five criteria: tradition, proportion of local raw materials, proportion of manual work, relation to the region and exceptional properties. The regional mark was originally aimed at tourists, but with a growing share of food it is also interesting within regions. The Association of Regional Marks annually provides as much as 5 million CZK for mark support. Licences cost companies around 1,500 CZK per year, and the larger companies as much as three times that amount. Other resources come from EU subsidies, member contributions or 
consulting. An added value of a mark is horizontal cooperation between mark holders. An example of this functioning is the collection of local food by local restaurants - producers 'send' customers to each other in the form of 'hiking trails', mutually selling each other their products, etc. (ARZ, 2017).

Regional products help build the identity of the region that forms the basis of the regional label in order to differentiate the relevant locality from other territorial units (Kašková et al., 2016). The label is one of the factors that influence customer purchasing behaviour (Czeczelewski et al., 2017; Nielsen, 2017).

Czechs still tend to be (in a Europe-wide comparison) extremely sensitive to price, but how they perceive it has changed in recent times - price itself is ceasing to be a key measure for much of the population. Instead, they are more interested in total value - a combination of several factors that they receive for their money. In addition to price, this includes in particular the quality of goods and services, trust and a generally pleasant relationship where one feels like an equal partner. The Customer experience emerges from a set of interactions between a customer and a product, a company, or part of its organization, which stimulate a reaction. This experience is strictly personal and implies the customer's involvement at different levels (rational, emotional, sensorial physical and spiritual). Its evaluation depends on the comparison between a customer's expectations and the stimuli coming from the interaction with the company and its offering in correspondence of the different moments of contact (Gentile et al. 2007).

The aim of this paper is to evaluate selected indicators associated with purchasing certified regional products. The studied characteristics focus on the knowledge and perception of several chosen microregional brands and on the purchase of a certified product itself.

\section{MATERIALS AND METHODS}

The methodological approach of this paper is generally based on the structure of explorative research. The research methods are based on an analysis of secondary data and primary data collection. Primary data was collected as part of a research project focused on regional designation of products in the Czech Republic. Respondents were contacted via an electronic questionnaire created using Google Docs. Snowball sampling method was used. The questionnaire contains closed, semiclosed and open questions. The article presents the outcomes of closed (dichotomous and multiple choice) and semiclosed questions. Data were collected in eight various micro-regions of the Czech Republic and obtained from as many as 1,390 respondents. Basic characteristics of the sample are illustrated in the following Tab. (Tab. I).

The individual regions are not represented uniformly; the data gathered in micro-regions

I: Characteristics of the sample

\begin{tabular}{|c|c|c|}
\hline & Abs. frequency & Rel. frequency \\
\hline \multicolumn{3}{|l|}{ Gender } \\
\hline Male & 442 & 31,80 \\
\hline \multicolumn{3}{|l|}{ Age } \\
\hline until 14 & 7 & 0,50 \\
\hline $25-34$ & 418 & 30,07 \\
\hline $35-44$ & 366 & 26,33 \\
\hline $45-54$ & 256 & 18,42 \\
\hline $55-64$ & 113 & 8,13 \\
\hline Secondary & 706 & 50,79 \\
\hline Tertiary & 639 & 45,97 \\
\hline \multicolumn{3}{|c|}{ Status towards the region } \\
\hline Local inhabitant & 713 & 51,29 \\
\hline Traveler & 382 & 27,48 \\
\hline Cottage & 55 & 3,96 \\
\hline Holiday-maker & 125 & 8,99 \\
\hline
\end{tabular}

Source: Authors, 2018 
of Jeseníky, Poohří and Krušnohoří constitute more significant portions of the sample. The representation of individual regions was as follows: Český ráj (Bohemian Paradise) - 9.21\%, Českosaské Švýcarsko (Czech-Saxon Switzerland) - 5.04\%, Haná - 6.91\%, Jeseníky - 21.22\%, Krkonoše (Krkonose Mountains) - 13.09\%, Krušnohoří (Ore Mountains) - 16.69\%, Orlické hory (Eagle Mountains) - 7.34\% and Poohří - 20.5\%.

The relationship between categorical variables was examined by Chi-square test of independency (Agresti, 2013). The null hypothesis, assuming no relationship between variables, was tested at the significance level of $5 \%$. If the resulted p-value for Chi-square test was less than the significance level, we rejected null hypothesis.

Table II provides an overview of the set hypotheses for the purposes of data analysis.

\section{RESULTS}

Nearly $46 \%$ of the respondents claim to have encountered a micro-regional brand. When compared with other designations of origin, these results show that the awareness of micro-regional designations stands approximately at the level of that of Czech Made brand. It therefore ranks among those less known. The respondents' awareness of other domestic designations of origin is considerably higher. By a large margin, the greatest number of the respondents declared the awareness of the KLASA brand - National Mark of Quality and Wines from Moravia, Wines from Bohemia, where the awareness of the brand within the sample reached almost $95 \%$ or $90 \%$.
These brands enjoy the most intensive marketing support out of the whole spectrum of brands surveyed.

On the other hand, micro-regional designations yield by far better results than the three examined designations guaranteed by the European Union, which are recognized by less than one third of respondents.

A detailed analysis of results in the individual micro-regions yields differing proportions of awareness of regional designations (Fig. 1).

According to Fig. 1 the highest awareness is found with respect to brands Haná Regionální produkt (56\%), Krkonoše Originální produkt (43\%) and Jeseníky Originální produkt (40\%). On the contrary, brands Českosaské Švýcarsko (26\%), Krušnohoří Regionální produkt (26\%) and Regionální produkt Českého ráje (27\%) rank among those least known to the respondents.

When a comparison is made of the number of certified products in each region and awareness of relevant regional brand there is no apparent link. The same conclusion can be reached for the duration of existence of individual brands and their awareness. In Fig. 1, individual regional brands are sorted by their year of origin, from the oldest to the youngest.

Table III shows the summary results for tested hypotheses $\left(\mathrm{HO}_{1}-\mathrm{HO}_{4}\right)$ defined in Tab. II. Based on the results, general awareness of regional brand correlates with respondents' age, education and also status toward the region. No dependence was proven in case of gender.

It is also clear from the results that awareness of regional brand is higher for respondents from

II: Sethypotheses

\begin{tabular}{lr}
\hline No. & Hypothesis \\
\hline $\mathbf{H}_{1}$ & General awareness of regional brand is not dependent on respondents' gender \\
$\mathbf{H} \mathbf{0}_{2}$ & General awareness of regional brand is not dependent on respondents' age \\
$\mathbf{H}_{3}$ & General awareness of regional brand is not dependent on respondents' education \\
$\mathbf{H}_{4}$ & General awareness of regional brand is not dependent on respondents' status toward the region \\
\hline
\end{tabular}

Source: Authors, 2018

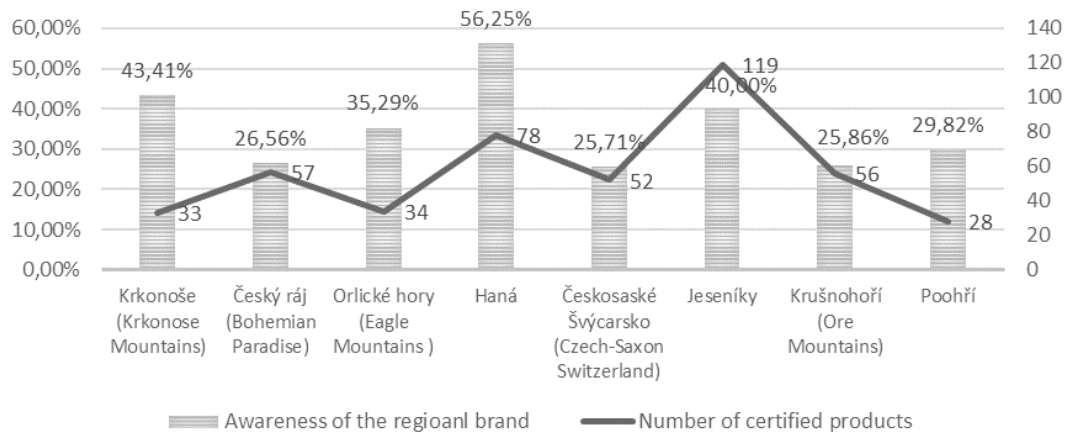

1: Comparison of awareness of the regional brand and number of certified product in each region Source: Authors, 2018 
lower age categories, with higher education and for residents of the surveyed regions.

The Association of Regional Brands [Asociace regionálních značek, ARZ] claims that brands guarantee especially the origin of a product in the given region, its quality, the fact that the product is environmentally friendly, and uniqueness arising from its relation to the region (e.g. The tradition, local materials, craftsmanship, regional motifs or other exceptional features).

The results of the survey show (Fig. 2) that the attribute most intensively perceived by the respondents is that of production in the given region. The attribute of a traditional product also turns out to be of great significance. ARZ states that the notion of Tradition may relate either to the given type of product, or to production technology (even though the product as such may be a novelty), or a company (which operates in a region for a certain time although it may produce new products or use new technologies). More than one half of respondents acknowledge certification as a guarantee of the local origin of the materials used. According to ARZ, products should be produced using local materials at least to a partial extent, i.e. materials originated in the territory of the given micro-region. Materials identified as local must not be substituted, blended or combined with other materials.

The respondents associate regional designations with quality to a lesser extent and the association with environmental friendliness is down to less than $20 \%$.

The Association of Regional Brands distinguishes three basic types of products that may be certified. These categories include products, services and experiences. Products are sub-divided into food and agricultural produce, handicraft products and natural products. Nearly two thirds of the respondents associate brands with the category of food and agricultural produce, one third of the respondents connect brands with handicraft products and a similar portion of respondents with natural products. A considerably lower number of respondents look upon regional brands in connection with experiences or services.

If a comparison is made between the results obtained in the individual types of products which the respondents associate with regional brands and the actual number of products registered in the individual categories (Fig. 3), it may be stated that

III: Results of tested hypotheses

\begin{tabular}{lcccc}
\hline \multicolumn{1}{c}{ Characteristic } & Chi-Square & df & p-value & H0 \\
\hline gender & 5,298 & 2 & 0,071 & cannot be rejected \\
age & 31,397 & 8 & 0,0001 & rejected \\
education & 51,564 & 8 & 0,0001 & rejected \\
status toward the region & 73,509 & 2 & 0,0001 & rejected \\
\hline
\end{tabular}

Source: Authors, 2018

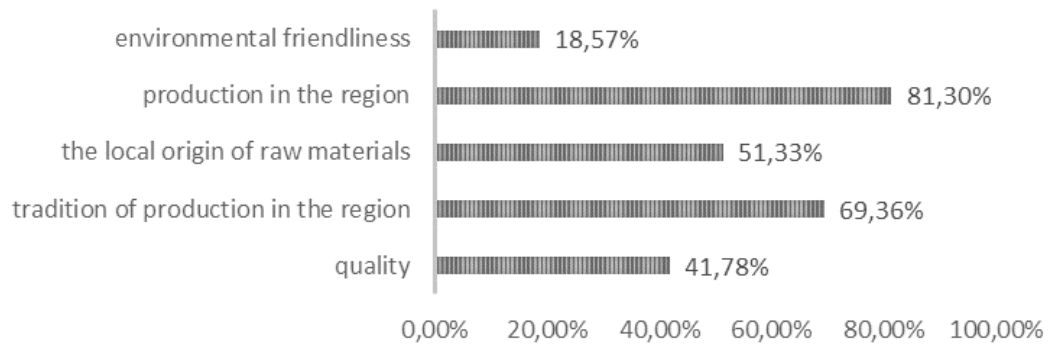

2: Characteristics associated with regional brand

Source: Authors, 2018

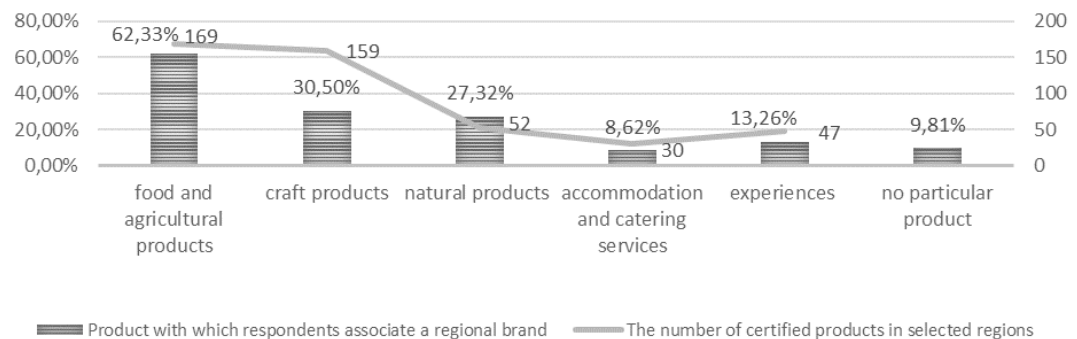

3: Comparison of type of product which respondents associate with the regional brand and number of certified product in selected regions Source: Authors, 2018 
the results tally well in case of food and agriculture products. The craft product situation is inconsistent. In fact there is almost same amount certified craft product like food, but awareness by respondents is only half in comparison to food. In case of experiences there is also mismatch with reality, since the total number of experiences certified is the lowest in all product categories, in spite of the fact that the respondents connect brands with experiences more often than with restaurant and accommodation services.

The respondents have most often encountered brands directly on the packaging of a certified product: almost in two thirds of all cases (Fig. 4). More than one third of the respondents have come across brands in promotional materials of the respective region and as many as $30 \%$ of them have seen brands in promotional materials of producers. Other communication channels of certain importance include those belonging to the "online" category, where websites of the given regions dominate. With a lower intensity, the respondents have noted brands on social networks or websites of producers. The communication channels that the respondents associate with brands to the least extent include websites of brand providers and television or radio coverage.

\section{DISCUSSION}

The state and various Czech and international organizations are trying to make consumers aware of quality products, for example by labelling them with various marks with a graphic logo, which should guarantee the quality of the products so labelled. The question, of course, is to what extent marks really provide a guarantee of quality raw materials and production. In general, only some of the logos are supported by legislative or national quality systems (such as KLASA, Regional Food, logos under the Czech Quality System under the Ministry of Industry and Trade, logos protected by the Association of Regions of the Czech Republic, the Food Chamber, Chamber of Commerce, etc.). Individual marks are supported financially and by marketing, both by the state and by individual associations. The most expensive and most state-promoted mark is KLASA, which, paradoxically, is also the mark that is the subject of the greatest criticism. This mark is most often accused of also being awarded to products that are not originally Czech.

Awareness of regional brands within the sample surveyed is around $46 \%$, a fact that signifies a worse result in comparison with the most of the other domestic designations of origin. On the other hand, such awareness within the sample is much higher when compared with European brands. In comparison with surveys of other authors who analysed the awareness of regional brands in their research, the result may be viewed as positive. Chalupová, Prokop and Rojík (2016), who examined the brand VYSOČINA regional product, recorded the awareness of the brand only by $31 \%$ of respondents.

Awareness of regional brands correlates with respondents' age, education and also status toward the region. Results also show that awareness is lower among older respondents with a lower level of education. Visitors of surveyed regions are also less aware than local residents. This may indicate the untapped potential of regional branding for tourism.

Based on the results achieved, the image of regional brands may be evaluated as follows. The perception of consumers considered, a brand is most often associated with tangible products, namely food and agricultural produce. Consumers view brands chiefly as a guarantee of production in the given region and a certain tradition. Brands are treated as a symbol of quality products by $40 \%$ of the respondents only. The attribute of ecology proves to be of a considerably lower importance in comparison with other attributes. Similar results were achieved in the research into regional products carried out by the company Nielsen (2017). Based on their findings, customers most often buy regional food $(83 \%)$ and beverages (38\%). Regional products are associated chiefly with tradition (53\%), quality (47\%) and the regional origin (41\%). The attributes of

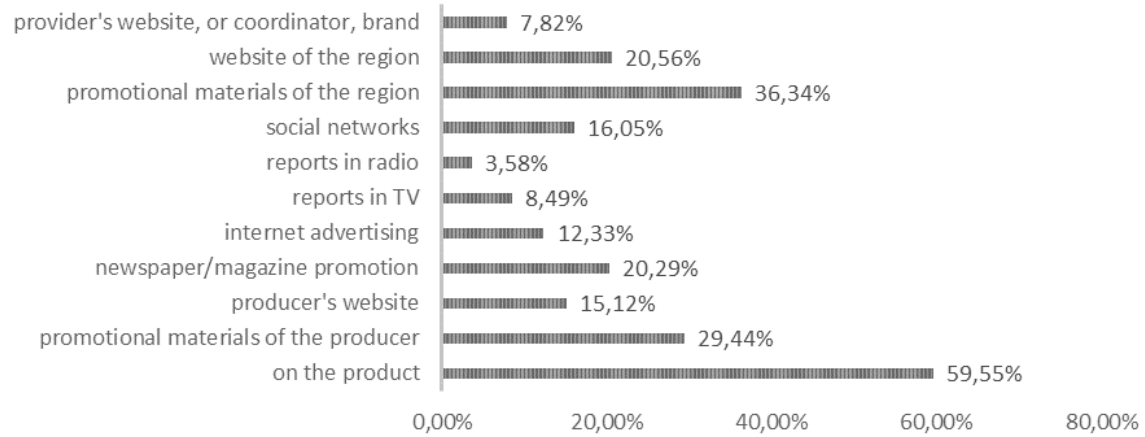

4: The type of media through which respondents encountered regional brand Source: Authors, 2018 
Nature (19\%) or the Environment (10\%) were found to be of a lesser importance also in this research.

Most often, the respondents take notice of brands on the packaging of a particular certified product. The results of the survey showed that websites of respective regions and promotional materials of individual producers constitute another communication channel. A noticeably unused potential has been found to exist in the area of social networks, which, though presently an important communication channel, had only $16 \%$ of the respondent notice regional brands. Another large space for improvement appears to be in the area of PR activities, since less than $10 \%$ (TV) or $5 \%$ (radio) of the respondents notice brands in the traditional media. In addition, websites of the Association of Regional Brands turn out to be of a lesser importance for putting brands "on the map".

\section{CONCLUSION}

In order to promote endogenous development and endogenous growth in regions, it is necessary to create a network environment for cooperating entities within a regional infrastructure that will allow for the transfer of technology and knowledge to the business entities environment. Via cluster support, a region can be 'sold' to companies, investors and, in some special cases, tourists. So-called "community developers" or institutions and agencies involved in the development and marketing of a given area, and building communication arenas to stimulate knowledge and information, play a major role in this effort. On the regional level, this issue can be demonstrated in the example of regional labelling (Čadilová, 2011; Mauroner and Zorn, 2017).

Based on research following opportunities arise: growing consumer interest in food origin and quality (Rudawska, 2014; Czeczelewski et al., 2017; Nielsen, 2017); growing interest of retailers to present themselves as distributors of quality products; relatively high interest of food businesses in quality schemes and certification systems creates a favourable environment that can stimulate farmers to also participate.

In the next part of the research, attention will be paid to the actual purchase of certified products. The research will also focus on the reasons for buying them or to place of purchase. Due to the charter of certified products, for example, farmers' markets seem to be a suitable place to sell. Pilař, Balcarová and Rojík (2016), for instance, in their study of instagram posts of the farmer's market visitors, draw attention to the repeated occurrence of the hashtag local.

\section{Acknowledgements}

Thispaperwassupported byInternalGrantAgency(IGA)FEM,CULSPrague[nr.20181004-Innovative activities in the context of sustainable development: the potential of regional labeling].

\section{REFERENCES}

AGRESTI, A. 2013. Categorical data analysis. Hoboken: John Wiley \& Sons.

BLAŽEK, J., ŽŹŽALOVÂ, P., RUMPEL, P. et al. 2013. Emerging regional innovation strategies in Central Europe: institutions and regional leadership in generating strategic outcomes. European urban and regional studies, 20(2): 275-294.

CHALUPOVÁ, M., PROKOP, M. and ROJÍK, S. 2016. European Countryside, 8(2): 109-122.

CZECZELEWSKI, J., TUCKI, A. and CZECZELEWSKA, E. 2017. The use of cluster analysis in the research on shopping preferences regarding regional products from Lubelskie voivodeship. Journal of Agribusiness and Rural Development, 1(43): 57-67.

ČADILOVÁ, K. 2011. Regional Branding throughout Europe: Experience sharing in the field of regional products support. Prague: Association of Regional Brands.

DTEST. 2017. Nové potravinářské předpisy. Časopis dTest, 2/2017. [Online]. Available at: https://www.dtest. cz/clanek-5645/nove-potravinarske-predpisy. [Accessed: 2018, January 10].

ELKINGTON, J. 1997. Cannibals with Forks: The Triple Bottom Line of Twenty-First Century Business. Oxford: Capstone.

GENTILE, C., SPILLER, N. and NOCI, G. 2007. How to Sustain the Customer Experience: An Overview of Experience Components That Co-create Value with the Customer. European Management Journal, 25(5): 395-410.

HRUBALOVÁ, L. and BUDZEL'OVÁ, P. 2017. Role of Regional products in Záhorie Region Development. Regionální rozvoj mezi teorií a praxí, 3: 72-84.

HRUŠKA, V., BROUMOVÁ, L. and PÍŠA, J. 2017. Assessing the Regionality Degree of Regional Products of the Ustí Region (Czechia). European Countryside, 9(4): 832-849.

CHROMÝ, P. 2009. Region and Regionalism [in Czech: Region a regionalismus]. Geografickérozhledy, 19(1): 2-5.

KAŠKOVÁ, M., CHROMÝ, P. and KUČERA, Z. 2016. Regional product labelling schemes constituting and reflecting the process of regions and regional identities construction: The case of Czechia. In: AAG Annual Meeting. San Francisco, March 29 $9^{\text {th }}-$ April $2^{\text {nd }} 2016$. 
KAŠKOVÁ, M., KUČERA, Z. and CHROMÝ, P. 2016. Místo a značka: place branding a problémy jeho konceptualizace [Place and brand: place branding and problems of its conceptualisation]. Informace Česká geografická společnost, 35(2): 1-16.

KAUFMANN, H. R. and DURST, S. 2008. Developing inter-regional brands. EuroMed Journal of Business, 3(1): 38-62.

KAŽMIERSKI, T. 2014. Regional branding of local products began in protected areas [in Czech: Regionální značení místních výrobků začalo v chráněných územích]. Ochrana př́rody, 1: 25-27.

KAŽMIERSKI, T. 2013. Branding of regional products in the Czech Republic [in Czech: Značení regionálních produktů v České republice]. Brno: Lipka - školské zařízení pro environmentální vzdělávání.

LEE, I. and ARCODIA, CH. 2011. The Role of Regional Food Festivals for Destination Branding. In: International Journal of Tourism Research, 13(4): 355-367.

LEE, W. J., O'CASS, A. and SOK, P. 2016. Why doesn't our branding pay off: optimising the effects of branding through innovation. European Journal of Marketing, 50(3/4): 509-529.

MAURONER, O. and ZORN, J. 2017. Cluster branding - a case study on regional cluster initiatives, cluster management, and cluster brands. International Journal of Innovation and Regional Development, 7(4): 290-312.

MINTA, S. 2015. Regional food products: only for tourists or also for residents. Agriculture $\sigma$ Forestry. 61(1): 51-58.

NIELSEN. 2017. Regional foods and products [in Czech: Regionální potraviny a výrobky]. Prezentace. Výzkumná agentura Nielsen a Asociace regionálních značek, srpen 2017. [Online]. Available at: https://docs.wixstatic. com/ugd/9b7c0e_dcf22f996dc844b38392731795b99210.pdf [Accessed: 2018, January 10].

PILAŘ, L., BALCAROVÁ, T. and ROJÍK, S. 2016. Farmers' Markets: Positive Feelings of Instagram Posts. Acta Universitatis Agriculturae et Silviculturae Mendelianae Brunensis, 64(6): 2095-2100.

RUDAWSKA, E. D. 2014. Customer loyalty towards traditional products - Polish market experience. British Food Journal, 116(11): 1710-1725.

SKOKAN, K. 2004. Competitiveness, Innovation and Clusters in Regional Development [in Czech: Konkurenceschopnost, inovace a klastry v regionálním rozvoji]. Ostrava: Repronis.

Klára Margarisová: margarisova@pef.czu.cz

Lucie Vokáčová: vokacova@pef.czu.cz

Kateřina Kuralová: kuralova@pef.czu.cz

Tomáš Hlavsa: hlavsa@pef.czu.cz 